\title{
EFFECT OF DIETARY INCLUSION OF FERMENTED PINEAPPLE PEEL WASTE ON PERFORMANCE AND EGG YOLK CHOLESTEROL LEVEL OF LAYING HENS
}

\author{
ADRIZAL ${ }^{1}$, Nurul HIDAYAT ${ }^{1}$, Yan HERYANDI ${ }^{2}$ and Maria Endo MAHATA $1 \bowtie \bowtie$ \\ ${ }_{1}^{1}$ utrition and Feed Technology Department, Faculty of Animal Science, Universitas Andalas, Padang, 25163, Indonesia \\ 2Department of Livestock Production, Faculty of Animal Husbandry Andalas University, Padang 25163, Indonesia \\ Email: maria@ansci.unand.ac.id; (D) ORCiD: 0000-0002-4692-9806 \\ Supporting Information
}

\begin{abstract}
The experiment was conducted to evaluate the effect of fermented-pineapple peel waste (FPPW) with indigenous microorganisms (IMO) solution from bamboo sprout on performance and egg yolk cholesterol of laying hen ration. In this experiment, a total number of 200 ISA Brown laying hens with 32 weeks old with $70 \%$ egg production and average egg weight $58.58 \mathrm{~g} / \mathrm{egg}$ were used. A completely randomized design was used in this experiment. Five different levels of supplementation with FPPW $(0,5,10$, 15 , and $20 \%$ ) were used in ration, and each treatment was replicated four times. The measured parameters were daily feed consumption, daily egg production, egg weight, egg mass, feed conversion ratio (FCR), and egg yolk cholesterol. The results indicated that FPPW with IMO solution from bamboo sprout as much as $20 \%$ reduced egg yolk cholesterol significantly, and did not affect daily feed consumption, daily egg production, egg weight, egg mass, and FCR significantly. It has been concluded that FPPW could be used up to $20 \%$ in laying hens rations without disrupting performance (daily feed consumption, hen day egg production, egg weight, egg mass, and FCR), and could reduce egg yolk cholesterol as much as $16.86 \%$.
\end{abstract}

Keywords: Bamboo, Laying hens, Performance, Pineapple peel, Waste.

\section{INTRODUCTION}

Waste materials from agriculture products have the potential to be used as poultry ration ingredients to exploit the remaining nutritional content. Pineapple peel waste is one of the waste materials that has not yet been widely used as a poultry feed. Pineapple production in Indonesia is around 1.39 million tons/year (Pariona, 2018). Base on Indonesia Central Bureau of Statistics (2017 and 2018), the pineapple export from Indonesia was 8.024.662 kg and 13.362 .430 $\mathrm{kg}$, respectively. As much as $30 \%$ of pineapple peel is produced from one pineapple fruit's processing into edible products (Campos et al., 2020). The nutrients content profile of pineapple peel waste on dry matter basis were $93.79 \%$ dry matter, $5.76 \%$ crude protein, $24.00 \%$ crude fiber, $0.93 \%$ crude fat, $6.08 \%$ ash, $0.53 \%$ calcium, $0.25 \%$ phosphorous, and it contains $3699.8 \mathrm{kcal} / \mathrm{kg}$ gross energy (Mahata et al., 2016), and up to $38.3 \mathrm{mg} / 100 \mathrm{~g}$ vitamin C (Ellong et al., 2015). Vitamin $C$ is known to increase the feed consumption in poultry (Torki et al., 2014; Abudabos et al., 2019).

These waste feedstuffs can be utilized by poultry; however the limiting factor for using pineapple peel waste as poultry feed is that the high crude fiber makes it difficult to digest (Aruna, 2019). Therefore it needs to be processed to reduce crude fiber content before adding it to the poultry feed. A fermentation process with an indigenous microorganisms (IMO) solution derived from bamboo sprouts is one method to reduce the crude fiber content in pineapple peel waste (Adrizal et al., 2017). The In vitro testing of bamboo sprouts which had been cultivated on cellulase-producing medium (Carboxymethyl Cellulose or CMC agar plate) revealed the presence of Bacillus thuringiensis, Bacillus aerius, Lactobacillus plantarum and Panus velutinus (Mahata, 2019). When IMO microorganisms were used to ferment pineapple peel, the crude fibre has been found to be reduced by $17.16 \%$ leaving $12.85 \%$ water, $87.15 \%$ dry matter, $8.95 \%$ crude protein, $2.08 \%$ crude fat, $0.16 \%$ calcium, $0.38 \%$ phosphorus, and $1190.47 \mathrm{kcal} / \mathrm{kg}$ metabolic energy (Adrizal et al., 2017). This fermented pineapple peel waste (FPPW) can be used to replace up to $12 \%$ of broiler ration without interfering with carcass performance and organ development (Heryandi et al., 2018). Present experiment evaluated the effect of FPPW on performance and egg yolk cholesterol of laying hens.

\section{MATERIALS AND METHODS}

\section{Laying hens and housing}

In current experiment a 200 number of ISA Brown laying hens that aged 32 weeks were used that had $70 \%$ egg production, average egg weight 58.58 and body weight of $1.62 \mathrm{~kg}$. The breed of laying hens was used was ISA Brown. It was purchased at the poultry shop in West Sumatra province, Indonesia. This research was conducted on an independent farm laying hens in West Sumatra, Indonesia. The adaptation period was carried out to adjust the laying hens with rations treated with fermented pineapple peel waste (FPPW) for one week (seven days). The cage used was a battery cage with 
as many as $\mathbf{2 0 0}$ cages. The light system was arranged appropriately with laying hens need in the night with lamp, and a long day the lamp is off.

\section{Date of study}

This research was conducted from 8th November 2018 to $2^{\text {nd }}$ January 2019 for a period of eight weeks.

\section{Ethical approval}

The present study was approved by the Animal Ethics Committee of Andalas University in Padang, Indonesia (No. 708/KEP/FK/2019).

\section{Vaccine and vitamins}

The vaccine given was Medivac Coryza T Suspension through subcutaneous. The vitamin given was a top mix produced by the feed industry in Indonesia named Medion. top mix composition for each $10 \mathrm{~kg}$ contain: $12.000 .000 \mathrm{IU}$ vitamin A, 2.000.000 IU vitamin D3, 8.000 IU vitamin E, 2.000 mg vitamin K3, $2.000 \mathrm{mg}$ vitamin B1, 5.000 mg vitamin B2, $500 \mathrm{mg}$ vitamin B6, $12.000 \mu \mathrm{g}$ vitamin B12, $25.000 \mathrm{mg}$ vitamin C, $6.000 \mathrm{mg}$ Calcium-D-pantothenate, $40.000 \mathrm{niacin}$, $10.000 \mathrm{mg}$ cholin chloride, $30.000 \mathrm{mg}$ methionine, $30.000 \mathrm{mg}$ lysine, $120.000 \mathrm{mg}$ manganese, $20.000 \mathrm{mg}$ iron, $200 \mathrm{mg}$ iodine, $100.000 \mathrm{mg}$ zinc, $200 \mathrm{mg}$ cobalt, $4.000 \mathrm{mg}$ copper, $10.000 \mathrm{mg}$ santoquin (antioxidant), $1.300 .000 \mathrm{mg}$ growth promoter.

\section{Experimental design and ration}

The experiment was designed in a completely randomized design using a treatment ration containing five different percentages of FPPW $(0,5,10,15$, and $20 \%)$, and each treatment was repeated four times. Rations containing $0 \%$ FPPW was control rations, and those containing 5, 10, 15, and 20\% FPPW were treatment rations. Laying hens have placed as many as ten birds in the battery cage for each control and treatment ration and its replication.

The ration was self-prepared using Yellow corn, palm oil, rice bran, top mix, cargill concentrate, stone flour, and fermented pineapple peels waste, as shown in Table 1. These mixed rations were formulated to be iso-protein (16\%) and iso-energy (2600 kcal/kg).

\section{Table 1 - Ration composition, nutrient content (\%), and metabolizable energy (kcal/kg ration) of the experimental} ration

\begin{tabular}{|c|c|c|c|c|c|c|c|c|c|}
\hline \multirow{2}{*}{$\begin{array}{l}\text { Experimental } \\
\text { ration \% (FPPW) }\end{array}$} & \multicolumn{9}{|c|}{ Feedstuffs (\%) } \\
\hline & Yellow corn & \multicolumn{2}{|c|}{$\begin{array}{l}\text { Concentrate for } \\
\text { laying hens }\end{array}$} & Rice bran & FPPW & $\begin{array}{l}\text { Palm } \\
\text { oil }\end{array}$ & $\begin{array}{l}\text { Top } \\
\text { mix }\end{array}$ & $\begin{array}{l}\text { Flour } \\
\text { stone }\end{array}$ & Total \\
\hline 0 & 44.00 & \multicolumn{2}{|c|}{28.00} & 23.00 & 0.00 & 0.25 & 0.50 & 4.25 & 100.00 \\
\hline 5 & 43.00 & \multicolumn{2}{|c|}{28.00} & 18.75 & 5.00 & 0.75 & 0.50 & 4.00 & 100.00 \\
\hline 10 & 42.00 & \multicolumn{2}{|c|}{28.00} & 14.50 & 10.00 & 1.25 & 0.50 & 3.75 & 100.00 \\
\hline 15 & 41.00 & \multicolumn{2}{|c|}{28.00} & 10.25 & 15.00 & 1.75 & 0.50 & 3.50 & 100.00 \\
\hline 20 & 40.00 & \multicolumn{2}{|c|}{28.00} & 6.00 & 20.00 & 2.25 & 0.50 & 3.25 & 100.00 \\
\hline \multirow{2}{*}{$\begin{array}{l}\text { Experimental } \\
\text { ration \% (FPPW) }\end{array}$} & \multicolumn{9}{|c|}{ Calculated analysis } \\
\hline & $\begin{array}{c}\text { Crude } \\
\text { protein (\%) }\end{array}$ & $\begin{array}{c}\text { Crude } \\
\text { fiber (\%) }\end{array}$ & $\begin{array}{l}\text { Crude } \\
\text { fat (\%) }\end{array}$ & Calcium (\%) & PA (\%) & \multicolumn{2}{|c|}{$\begin{array}{c}\text { Methionine } \\
\text { (\%) }\end{array}$} & $\begin{array}{l}\text { Lysin } \\
\text { (\%) }\end{array}$ & $\begin{array}{c}\text { ME } \\
\text { (kcal/kg) }\end{array}$ \\
\hline 0 & 16.48 & 5.80 & 3.93 & 3.47 & 0.26 & \multicolumn{2}{|c|}{0.15} & 0.22 & 2623.92 \\
\hline 5 & 16.37 & 6.11 & 4.23 & 3.42 & 0.27 & \multicolumn{2}{|c|}{0.14} & 0.20 & 2623.77 \\
\hline 10 & 16.27 & 6.41 & 4.53 & 3.37 & 0.28 & \multicolumn{2}{|c|}{0.13} & 0.17 & 2623.62 \\
\hline 15 & 16.16 & 6.72 & 4.59 & 3.33 & 0.28 & \multicolumn{2}{|c|}{0.11} & 0.14 & 2623.47 \\
\hline 20 & 16.05 & 7.02 & 5.12 & 3.28 & 0.29 & \multicolumn{2}{|c|}{0.10} & 0.12 & 2623.32 \\
\hline
\end{tabular}

\section{Preparation of IMO solution from bamboo sprout}

Chopped bamboo sprouts weighed as much as $1000 \mathrm{~g}$ and mix with $3 \mathrm{~L}$ of rice water and $200 \mathrm{~g}$ of palm sugar. Furthermore, stirred until homogeneous and incubated under anaerobic conditions for 15 days. The harvested bamboo sprouts IMO solution was separated between the liquid and the bamboo sprouts dregs, this liquid was the indigenous microorganisms.

\section{Preparation of FPPW}

Pineapple peel was obtained from pineapple home industry processing in Kampar Regency, Riau province. This province is the second-largest pineapple producer on the island of Sumatra, Indonesia. Pineapple peel was prepared by cleaned, and then they were weighed as much as $500 \mathrm{~g}$ and put in a fermentor. As much as $325 \mathrm{ml}$ IMO solution was added and mixed until the mixture became homogeneous. Furthermore, it was incubated for one week. The fermentation process was stopped after incubation finished, dried under the sun, the milled becomes powder. Furthermore, it was ready to be used as poultry feed (Adrizal et al., 2017). 


\section{The measured parameters}

Daily feed consumption is calculated by the total number of rations given to laying hens for one week minus the number of rations left for one week, then divided by the number of days for one week (7 days).

The hen day egg production was measured by the method of Cesari et al. (2014) with the formula as follows:

$$
\text { Hen day egg production }=\frac{\begin{array}{c}
\text { The number of eggs produced on } \\
\text { the day of measurement }
\end{array}}{\begin{array}{c}
\text { The number of live laying hens on } \\
\text { the day of measurement }
\end{array}} \times 100 \%
$$

The following formula measured egg weight:

Egg weight $=\frac{\text { The weight of eggs produced in each unit }}{\text { The number of eggs produced in each unit }}$

The Egg mass was calculated using the method of Cesari et al. (2014) with the following formula:

Egg mass = hen day egg production (\%) - egg weight (g).

The feed conversion ratio was calculated using the method of Kulshreshtha et al. (2014) with the following formula:

$$
\text { Feed conversion ratio }=\frac{\text { Ration consumed }(\mathrm{kg})}{\text { Egg production } \mathrm{x} \text { egg weight }(\mathrm{kg})}
$$

Egg yolk cholesterol measurements were carried out by using spectrophotometry. After weighing 1 gram of egg sample and putting it in a centrifuge tube which contained $10 \mathrm{ml}$ of acetone alcohol solution (1:1) and then warming was performed until the solution boiled. After cooling the solution, it was centrifuged at 3000 rpm for 15 minutes, the supernatant was taken and then evaporated on a boiling water bath until the residue remained, after that, dilution was carried out with chloroform. The reading performed at $680 \mathrm{~nm}$, after the color turned green ( \pm 5 minutes). The calculation of cholesterol levels was calculated by comparing the absorbance with the cholesterol standard curve.

The equation was: $Y=2.354 \mathrm{X}+0.005$

$\mathrm{Y}=$ Absorbance of cholesterol sample; $\mathrm{X}=$ level of cholesterol $(\mathrm{mg} / 100 \mathrm{ml})$

\section{Statistical analysis}

The research data were analyzed using analysis of variance for a Completely Randomized Design. The significance of differences between treatments were tested with Duncan's Multiple Range Test (DMRT), with a significant value at $\mathrm{P}<0.05$ and $\mathrm{P}<0.01$ (Steel and Torrie, 1995).

\section{RESULTS AND DISCUSSUON}

The results showed the inclusion of $0,5,10,15$ and 20\% FPPW had no significant effect $(P>0.05)$ on daily feed intake, hen day egg production, egg weight (Table 2). Over time, no difference in egg mass, and FCR from the five treatments were observed ( $P>0.05$; Table 3 ). The use of FPPW as much as 0,5 , and $10 \%$ in rations had no significant effect $(P>0.05)$ on egg yolk cholesterol, however the inclusion of 15 and $20 \%$ FPPW in ration had a highly significant $(P<0.01)$ effect on lowering egg yolk cholesterol (Table 3).

Increasing the use of the FPPW up to $20 \%$ changed the color of ration the initially yellowish ration to brown as the amount of corn was reduced from $44 \%$ to $40 \%$. This did not appear to have any effect on the palatability of the ration as the hens seemed to find the taste of FPPW attractive. Besides, high vitamin C content in FPPW is thought to trigger an increasing palatability of the ration. Pineapple is rich in Vitamin C containing $6.40 \mathrm{mg} / 100 \mathrm{ml}$ (Nweze et al., 2015). Inclusion of $250 \mathrm{~g} / \mathrm{kg}$ vitamin $\mathrm{C}$ in laying chicken ration has been found to increase the feed consumption by $0.75 \%$ Torki et al. (2014). Furthermore, Abudabos et al. (2019) stated the inclusion of vitamin C as much as $200 \mathrm{mg} / \mathrm{L}$ in broiler ration with environment's temperature is $32{ }^{\circ} \mathrm{C}$, showed increasing the feed consumption of broiler up to $0.98 \%$.

FPPW also contains a bromelain enzyme which has been shown to not interfere with feed consumption, reduce blood serum cholesterol, and liver cholesterol in laying hens (Lien et al., 2012). Replacing up to $12 \%$ of ration with FPPW has been shown to have no effect on the feed consumption (Handika, 2017). The average daily feed consumption of laying hens in this study ranged from 116.01 to $118.25 \mathrm{~g} / \mathrm{bird} / \mathrm{d}$. These results are similar to those reported by Yenice et al. (2019) who also found the inclusion of bromelain enzymes in laying hen ration did not affect daily feed consumption which remained at 114 to $119 \mathrm{~g} / \mathrm{bird} / \mathrm{d}$. Daily feed consumption affects hen day egg production, egg weight, and egg mass. In this study, the inclusion of the FPPW up to $20 \%$ had no effect on consumption so hen day egg production, egg weight, and egg mass also remained the same. Other determinants of egg production are ration nutrient content, age of livestock, protein level, production period, energy, fat, vitamins, mineral rations, and water (Suprijatna, 2005; Agustina and Purwanti, 2012), which remained similar for all treatments. Nutrition contained in each treatment was equivalent as it was formulated to be iso-protein (16\%) and iso-energy $(2600 \mathrm{kcal} / \mathrm{kg})$, and the age of all laying hens was 32 weeks. The results of this study are lower than reported by Yenice et al. (2019), who found the inclusion of bromelain enzymes in rations of laying hens did not affect hen day egg production which was 87.7 to $90 \%$. 
Inclusion of FPPW did not affect egg weight as it did not affect daily feed consumption or subsequent nutrient intake or any other factors that influence egg weight such as amino acid intake, genetic traits, age, weight gain, and drugs (Keshavarz, 2003; Hartono and Kurtini, 2015; Saputra et al., 2016). The average egg weight in this study ranged from 62.88 to $63.68 \mathrm{~g} / \mathrm{egg}$ which are almost the same as those reported by Lien et al. (2012) who found the use of bromelain enzymes in laying hens rations did not disturb egg weight which was 64.87 to $66.03 \mathrm{~g} / \mathrm{egg}$. The inclusion of FPPW in the ration also did not affect egg mass. This is to be expected as egg mass is the product of egg weight and egg production. Ration that was composed of up to $20 \%$ of FPPW did not affect FCR due to the nutritional content of ration in each treatment being the same for all treatments. According to Andriyanto et al. (2015), one of the factors affecting FCR is nutrition quality. The average FCR in this study ranged from 2.65 to 2.83 . The result of this study was higher than those reported by Yenice et al. (2019) who measured a FCR range from 197 to 2.01.

The use of FPPW had a significant $(P<0.05)$ impact on egg yolk cholesterol (Table 3$)$, decreasing the egg yolk cholesterol content to $16.86 \%$. The decrease of egg yolk cholesterol in this study was due to the activity of the bromelain enzyme contained in the FPPW which was $0,0.0016,0.0032,0.0048,0.0064 \mathrm{U} / \mathrm{mL}$ for treatments $A, B, C, D$, and $E$, respectively. Bromelain enzyme is a sulfhydryl protease enzyme that can hydrolyze proteins into simple water soluble amino acids (Gautam et al., 2010). The biological effects of bromelain are related to their proteolytic activity (MazorraManzano et al., 2018). The structure of the bromelain enzyme is resistant to stomach acid so up to $40 \%$ can be absorbed in the digestive tract of livestock (Lien et al., 2012). The cholesterol reducing mechanism of bromelain is not clearly understood. Cholesterol in the body comes from diet and the liver (Murray et al., 2000). Hu et al. (2020) reported that bromelain could inhibit the absorption of fatty acids and the secretion of Very Low-Density Lipoprotein (VLDL), further reported that giving bromelain as much as $20 \mathrm{mg} / \mathrm{kg}$ in rats fed a high-fat diet for 12 weeks can reduce glycerol levels and fat accumulation in the liver. Bromelain breaks down the plaque on the walls of blood vessels improving blood circulation (Kelly, 1996). Previous researchers reported that bromelain enzyme in laying hen ration can reduce both blood serum and liver cholesterol (Lien et al., 2012; Yenice et al., 2019).

\section{Table 2 - The average daily feed consumption, hen day egg production, and egg weight of laying hens fed FPPW}

\begin{tabular}{lccc} 
Treatment (FPPW \%) & Daily feed consumption (g/bird/d) & Hen day egg production (\%) & Egg weight (g) \\
\hline 0 & $117.86 \pm 0.89$ & $70.92 \pm 1.67$ & $62.96 \pm 2.75$ \\
5 & $116.01 \pm 2.24$ & $69.64 \pm 4.26$ & $63.24 \pm 0.74$ \\
10 & $118.25 \pm 1.07$ & $65.66 \pm 7.10$ & $62.88 \pm 1.95$ \\
15 & $117.17 \pm 0.98$ & $69.08 \pm 6.80$ & $62.95 \pm 1.14$ \\
20 & $117.89 \pm 0.47$ & $66.28 \pm 5.72$ & $63.68 \pm 0.30$ \\
SE & 0.64 & 2.74 & 0.82 \\
P-value & NS & NS & NS \\
\hline FPPW= fermented pineapple peel waste, NS= non-significant & & \\
\hline
\end{tabular}

Table 3 - The average egg mass, feed conversion ratio, and egg yolk cholesterol of laying hens fed FPPW

\begin{tabular}{lccc} 
Treatment (FPPW \%) & $\begin{array}{c}\text { Egg mass } \\
(\mathrm{g})\end{array}$ & Feed conversion ratio & $\begin{array}{c}\text { Egg yolk cholesterol } \\
(\mathbf{m g} / 100 \mathrm{~g})\end{array}$ \\
\hline 0 & $44.65 \pm 2.35$ & $2.65 \pm 0.13$ & $518.07^{\mathrm{a}}$ \\
5 & $4.06 \pm 2.36$ & $2.66 \pm 0.19$ & $519.55^{\mathrm{a}}$ \\
10 & $41.49 \pm 3.57$ & $2.88 \pm 0.25$ & $480.35^{\mathrm{ab}}$ \\
15 & $43.24 \pm 3.53$ & $2.74 \pm 0.27$ & $468.02^{\mathrm{bc}}$ \\
20 & $42.21 \pm 3.61$ & $2.83 \pm 0.24$ & $430.70^{\mathrm{c}}$ \\
SE & 1.57 & 0.11 & 14.81 \\
P-value & $\mathrm{NS}$ & $\mathrm{NS}$ & $\mathrm{P}<0.01$ \\
SE= Standard error, FPPW $=$ fermented pineapple peel waste; a,b,c = Means in a column that are not followed by the same letter are \\
significantly different at (P<0.01).
\end{tabular}

\section{CONCLUSION}

Fermented pineapple peel waste could be used up to $20 \%$ in laying hens rations without disrupting performance (daily feed consumption, hen day egg production, egg weight, egg mass, and feed conversion ratio), and can reduce egg yolk cholesterol as much as $16.86 \%$.At the level $20 \%$, obtained the daily feed consumption was $117.89 \mathrm{~g} / \mathrm{bird} / \mathrm{d}$, hen day egg production $66.28 \%$, egg weight $63.68 \mathrm{~g}$, egg mass $42.21 \mathrm{~g}$, feed conversion ratio 2.83 , and egg yolk cholesterol 430.70 $\mathrm{mg} / 100 \mathrm{~g}$.

\section{DECLARATIONS}

Corresponding author

E-mail: maria@ansci.unand.ac.id 


\section{Authors' contribution}

Adrizal and Maria Endo Mahata participated in all stages of the research, namely the research design, the conduct of the experiment, sample analysis, data analysis, writing, and editing of articles. Nurul Hidayat participated in conducting the investigation, Yan Heryandi was responsible for data analysis. All authors participated in writing the article.

\section{Conflict of interests}

All authors declared they have no conflict of interest concerning the work presented in this manuscript.

\section{Acknowledgements}

The funding for this research came from the Universitas Andalas Professors' grant. It is appreciated to the Rector of Universitas Andalas and the Institute for Research and Community Service [Lembaga Penelitian dan Pengabdian Masyarakat] of Universitas Andalas for funding and facilitating this research.

\section{REFERENCES}

Abudabos AM, Al-Owaimer AN, Hussein EOS and Ali MH (2019). Effect of natural vitamin C on performance and certain haematoBiochemical values in broiler chickens exposed to heat stress. Pakistan Journal of Zoology, 50(3): 951-955. DOI: http://dx.doi.org/10.17582/journa I.pjz/2018.50.3.951.955

Adrizal, Mahata ME, Heryandi $Y$ and Amizar R (2017). Evaluation of pineapple (Ananas Comosus. (L.) Merr) waste fermentedusing different local microorganism solutions as poultry feed. Pakistan Journal of Nutrition, 16(2): 84-89. Google scholar ; D01: https://doi.org/10.3923/pjn.2017.84.89

Agustina and Purwanti (2012). Poultry Nutrition Science. House of Knowledge [llmu Nutrisi Unggas. Rumah Pengetahuan]. Solo, Indonesia, Available at: https://scholar.google.co.id/scholar?hl=id\&as_sdt=0,5\&cluster $=750698227009798170$

Andriyanto AS, Satyaningtijas R, Yufiadri R, Wulandari VM, Darwin and Siburian SNA (2015). Broiler chicken performances and feed digestibility treated with multi-dose testosterone hormone [Performan dan kecernaan pakan ayam broiler yang diberi hormone testosterone dengan dosis bertingkat]. Journal of Acta Veterinaria Indonesiana, 3(1): 2937. Available at: https://journa l.ipb.ac.id/index.php/actavetindones/article/view/11191

Aruna TE (2019). Production of value-added product from pineapple peels using solid state fermentation. Innovative Food Science and Emerging Technologies, 57: 102193. DOI: https://doi.org/10.1016/j.ifset.2019.102193

Campos DA, Ribeiro TB, Teixeira JA, Pastrana L, and Pintado MM (2020). Integral valorization of pineapple (Ananas comosus L.) By-products through a green chemistry approach towards added value ingredients. Food, 9: 60; Google scholar ; DOI: http://dx. doi.org/10.3390/foods9010060

Cesari V, Mangiagalli MG, Giardini A, Galimberti P, Carteri S, Gallazzi D and Toschi I (2014). Egg quality and productive performance of laying hens fed different levels of skimmed milk powder added to a diet containing Lactobacillus acidophilus. Poultry Science, 93(5): 1197-1201. Google scholar ; DOI: https://doi.org/10.3382/ps.2013-03518

Ellong EN, Billard C, Adenet S and Rochefort K (2015). Polyphenols, carotenoids, vitamin C content in tropical fruits and vegetables and impact of processing methods. Food and Nutrition Sciences, 6: 299-313. Google scholar ; DOI: http://dx.doi.org/10.4236/fns.2015.63030

Gautam SS, Mishra S, Dash V, Amit K and Rath G (2010). Cooperative study or extraction, purification and estimation of bromelain form stem and fruit of pineapple plant. Thai Journal of Pharmaceutical Sciences, 34(2010): 67-76. Available at: https://www.thaiscience.info/journals/Article/TJPS/10576308.pdf

Handika ER (2017). Effect of pineapple peel waste (Ananas comusus (L) Merr) fermented product of local microorganisms (LM) in rations on broiler performance [Pengaruh limbah kulit nenas (Ananas comusus (L) Merr) produk fermentasi mikroorganisme lokal (MOL) dalam ransum terhadap performa broiler]. Skripsi- Universitas Andalas, Padang. Available at: http://scholar.unand.ac.id/31203/

Hartono M, and Kurtini T (2015). The Effect of Probiotic Supplements on Layer Performance [Pengaruh probiotik terhadap performa ayam petelur]. Journal of Applied Agricultural Research, 15(3): 214-219. Available at: http://repositoty.lp pm.un ila.ac.id/6754/1/Jurnal\%20MH\%20Probiotik.pdf

Heryandi Y, Adrizal, Ningsih N and Mahata ME (2018). Carcass characteristics and organ development of broilers fed Fermented Pineapple Peel [Ananas comosus (L.) Merr] waste using a local microorganism solution derived from bamboo sprouts. International Journal of Poultry Science, 17: 229-233. Google scholar ; DOI: https://doi,org.10.3923/ijps.2018 $\underline{.229 .233}$

Hu PA, Chen CH, Guo, BC, Kou YR, and Lee TS (2020) Bromelain confers protection against the non-alcoholic fatty liver disease in male c57bl/6 mice. Nutrients, 2020 (12): 1-15. Google scholar ; DOI: https://doi,org.10.3390/nu12051458

Indonesia Central Bureau of Statistic (ICBS) (2017). Statistics of Indonesia's annual fruit and vegetable crops 2017 [Statistik tanaman buah-buahan dan sayuran tahunan Indonesia 2017]. ISSN: 2088-8406. No. Publikasi: 05120.1807. Katalog: 5205010. Available at: https://www.bps.go.id/publication/2018/10/05/081665ec9eb65fdce8a69473/st atistiktanaman-buah-buahan-dan-sayurantahunan-indonesia-2017.html

Indonesia Central Bureau of Statistic (ICBS) (2018). Statistics of Indonesia's annual fruit and vegetable crops 2018 [Statistik tanaman buah-buahan dan sayuran tahunan Indonesia 2018]. ISSN: 2088-8406. No. Publikasi: 05120.1901. Katalogg: 5205010. Available https://www.bps.go.id/publication.html?Publikasi\%5BtahunJudul\%5D=2018\&Publikasi\%5BkataKunci\%5D=Statistik+Tana man+Buah\%E2\%80\%90buahan+dan+Sayuran+Tahunan+Indonesia+\&yt0=Tampilkan

Kartasudjana R and Suprijatna (2006). Poultry Management [Manajemen Ternak Unggas]. Penebar Swadaya. Jakarta. Available at: https://scholar.google.co.id/scholar?hl=id\&assdt=0,5\&clu s ter=131329207522 2176466 
Kelly GS (1996). Bromelain: a literature review and discussion of its therapeutic application. Alternative Medicine Review, 1(4): 243-257. Available at: https://www.foundationa Imedicinereview.com/wp-content/uploads/2019/02/v1-4-243.pdf

Keshavarz K (2003). Effects of reducing dietary protein, methionine, choline, folic acid, and vitamin B12 during the late stages of the egg production cycle on performance and egg shell quality. Poultry Science, 82(9): 1407-1414. Google scholar ; DOI: https://doi:10.1093/ps/82.9.1407

Kulshreshtha G, Stratton G, Rathgeber B, Thomas N and Evan F (2014). Feed supplementation with red seaweeds, Chondrus crispus and Sarcodiotheca gaudichaudii, affects performance, egg quality, and gut microbiota of layer hens. Poultry Science, 93(12): 2991-3001. Google scholar ; DOI: https://dx.doi.org/ 10.3382/ps.2014-04200

Lien TF, Cheng YH and Wu CP (2012). Effects of Supplemental Bromelain on Egg Production and Quality, Serum and Liver Traits of Laying Hens. Journal of Animal Science Advances, 2(4): 386-391. Available at: https://www.semanticscholar.org/paper/Effects-of-Supplemental-Bromelain-on-Egg-Production-LienCheng/8013689a1a7b93a3248180d99aa52620347c3b1e

Mahata ME, Heryandi $Y$ and Adrizal (2016). Fermentation of pineapple waste (Ananas comosus (L.) Merr) with local microorganisms (LM) for poultry feed. Professor Research Grant Research Report [Fermentasi limbah nenas (Ananas comosus (L.) Merr) dengan mikroorganisme lokal (MOL) untuk pakan ungags]. Laporan Penelitian Hibah Riset Guru Besar. Universitas Andalas, First Year, Padang..

Mahata ME (2019). Processing pineapple peel waste with local microorganism for poultry feed. Professor's inauguration scientific oration, Universitas Andalas, Padang, Indonesia. Available at: https://www.youtube.com/watch?v=b3LjYaDCO4k

Mazorra-Manzano MA, Ramírez-Suarez JC and Yada RY (2018). Plant proteases for bioactive peptides release: A review. Critical reviews in Food science and Nutrition, 58(13): 2147-2163. Google scholar ; DOI: https://doi:10.1080/10408398.2017.1308312

Murray RK, Granner DK, Mayes PA and Rodwell VW (2000). Harper's Biochemistry. Publisher of Medical Book ECG, Jakarta. Available at: http://library.um.ac.id/free-contents/printbook5.php/koleksi-digital-perpustakaan-36281.html

Nweze CC, Abdulganiyu MG and Erhabor OG (2015). Comparative analysis of vitamin C in fresh fruits juice of Malus domestica, Citrus sinensi, Ananas comosus and Citrullus lanatus by iodometric titration. International Journal of Science, Environment and Technology, 4(1): 17-22. Available at: http://www.ijset.net/journal/502.pdf

Pariona A (2018). Top Pineapple producing Countries-WorldAtlas.com. Available at: https://www.worldatlas.com/articles/toppineapple-pro ducing-countries.html

Saputra DR, Kurtinib T dan Erwantob (2016). The effect of using feed additive on ration with different doses for egg weight and haugh unit value of layer egg. Jurnal IImiah Peternakan Terpadu, 4(3): 230-236. Available at: https://media.neliti.com/media/publications/233333-pengaruh-penambahan-feed-aditif-dalam-ra-2c0ea78a.pdf

Steel RGD and Torrie JH (1995). Statistical principles and procedures of a biometric approach. $2^{\text {nd }}$ edition, translated by Bambang Sumatri. PT. Gramedia Pustaka Utama, Jakarta, Indonesia. Available at: https://onesearch.id/Record/IOS3774.JAKPU000000 000005505

Suprijatna $E$ (2005). The effect of dietary protein level in growing periods on egg production in laying period of medium type layer. Journal of the Indonesian Tropical Animal Agriculture. Faculty of Animal Husbandry. Diponegoro University. Semarang. Available at: http://www.jppt.undip.ac.id/pdf/30(2) 2005p119-126.pdf

Torki M, Zangeneh S and Habibian M (2014). Performance, egg quality traits, and serum metabolite concentration of laying hens affected by dietary supplemental chromium picolinate and vitamin $C$ under a heat-stress. Biological Trace Element Research, 157(2), 120-129. Google scholar ; DOI: https://doi:10.1007/s12011-013-9872-8

Yenice G, Iskender H, Dokumacioglu E, Kaynar O, Kaya A, Hayirli A and Sezmis G (2019). Dietary bromelain supplementation for improving laying performance, egg quality and antioxidant status. European Poultry Science, 83: 1-16. Google scholar ; DOI: https://doi:10.1399/eps.20 19.272 